\title{
THE UNDERSTANDABILITY OF FINANCIAL STATEMENTS IN THE DECISION-MAKING PROCESSES OF INSOLVENCY PROCEEDINGS
}

\begin{abstract}
A financial statement is the only source of information about the financial condition of an entity. Its wide use in bankruptcy prediction proves its informational value. In many countries, the financial statement or elements of it constitute a database of information on the bankruptcy process. The purpose of this paper is to analyse the theoretical and practical aspects of using financial statements as a source of information in the bankruptcy process when decisions are made about the future of the debtor company. Empirical research was carried out in four of 46 district courts conducting insolvency proceedings in Poland. The research showed that, at this stage, neither regulations nor court practice guarantee that the content of the financial statements used in bankruptcy proceedings is intelligible.
\end{abstract}

Keywords: bankruptcy, insolvency, understandability of financial statements, quality of financial statements.

JEL Classification: M41.

\section{Introduction}

The regulations of national bankruptcy laws affect the course and efficiency of proceedings and thus are designed to improve the functioning of the national economies of individual countries (Wessels et al. 2009, p. 1). Given that effective implementation of bankruptcy proceedings requires credible and reliable information, national insolvency laws are required to make provision for their documentation. We can conclude from a study conducted by Smith and Strömberg (Smith \& Strömberg 2004) that in 
most of the countries investigated the laws mainly oblige debtors to submit information on the value of assets, such as lists of estate assets and claims or a preliminary valuation of assets, when initiating bankruptcy proceedings. In some of the countries surveyed, the database supporting the bankruptcy process also contains documents created within the accounting system. In Japan, for example, the verification mechanism requires debtors to furnish their own balance sheet and in France to present a financial statement. The law in Poland ${ }^{1}$ requires debtors to submit selected elements of financial statements and other financial data based on subjective estimates to the court (Bauer 2014). Yet in view of studies that have demonstrated the paucity of economic knowledge about bankruptcy (Mączyńska 2008), and even problems with the quality of the financial information necessary to predict it (Wędzki 2012, p. 178), it is questionable whether the quality of the financial statements that form part of the database supporting the bankruptcy process is sufficient to support decision-making regarding the future of debtor companies.

Moreover, the way that existing accounting rules are applied means that the pictures companies project of themselves can be far from the economic truth (Mączyńska 2009, p. 51). That it is not possible to conduct a thorough evaluation of owner-occupied properties, which often causes significant distortion of information about the debtor's financial situation ${ }^{2}$ has, for example, attracted considerable criticism. The law requires non-operational companies in bankruptcy proceedings to produce only a minimal amount of accounting information. This follows from the basic premise that the requirements to produce accounting information are tailored to the needs of companies continuing business operations, rather than attuned to the final phase of a company's life-cycle, even though this may last for several years ${ }^{3}$ (Walińska \& Jędrzejewski 2009, p. 165). It is noteworthy that the bankruptcy process in Poland means not only the loss of the ability to continue operating, but also the restructuring of companies seeking arrangement bankruptcies ${ }^{4}$.

\footnotetext{
${ }^{1}$ Bankruptcy and Reorganisation Act (2003), Restructuring Act (2015).

${ }^{2}$ See, for example, Kumor \& Strojek-Filus (2011), Gawron (2012) and Bauer (2014).

${ }^{3}$ The average duration of bankruptcy proceedings in Poland is three years (Doing Business Report, available on-line at http://www.doingbusiness.org/data/exploreeconomies/poland\# resolving-insolvency).

${ }^{4}$ Until the end of 2015 bankruptcy proceedings in Poland could be initiated with the intent to liquidate the assets of the insolvent debtor or to reach an arrangement with creditors. From 1 January 2016 the conduct of proceedings with the intent to make an arrangement, which in fact are restructuring proceedings, has been regulated by the Restructuring Act. However, bankruptcy proceedings initiated before the end of 2015 can be conducted in the same way as those intended to reach an arrangement with creditors. Due to the duration of the bankruptcy proceedings, insolvency proceedings leading to an arrangement are still an ongoing matter. In accordance
} 
The information derived from financial statements can also be used to evaluate activities in periods preceding the filing of the bankruptcy petition and thus improve the court's decision-making process with regard to debtor companies.

The deliberations in this paper are based on the belief that, though a financial statement is not the only source of information on debtors during bankruptcy proceedings in Poland, the legitimacy of including the financial statement in the information database depends on it retaining features that enable that data to be understood.

The aim of this paper is to identify the legal conditions affecting the clarity of the information from financial statements, which may form a base for assessing the financial situation of debtors in the initial stage of bankruptcy proceedings. This paper also addresses the practical difficulties of implementing financial reporting legislation that must be negotiated by debtor companies that have begun bankruptcy proceedings in court. The study sets out first to enlarge our knowledge of the regulations affecting the clarity of financial statements and business activities of entities in bankruptcy, before proceeding to evaluate the current state of affairs and to suggest potential paths for change.

There are three phases to the study:

- a review of the literature on the qualitative characteristics of financial statements,

- an analysis of corporate financial reporting legislation relevant to companies in bankruptcy proceedings in Poland,

- empirical research conducted on a representative sample of enterprises in bankruptcy proceedings in Poland.

The study seeks answers to the following questions:

1) Does the Bankruptcy Act in Poland require debtors to provide financial statements that their readers can understand?

2) Does the practice of bankruptcy proceedings in Poland ensure the clarity of the information included in financial statements?

These questions have been prompted by the literature review and by the author's previous studies of the financial statements of entities in insolvency proceedings.

with the empirical research it contains, this paper discusses the understandability of financial statements in bankruptcy proceedings begun before the end of 2015. 


\section{Understandability as a Qualitative Characteristic of Financial Statements}

Numerous scientific studies, legal regulations and accounting textbooks refer to issues related to the qualitative characteristics of financial statements, which are mainly considered in the context of the usefulness of financial statements to investors. The major sources of direction and guidance for the material to be contained in financial reports are IFRS (IFRS 2014) and the Conceptual Framework for Financial Reporting, whose latest definition of the qualitative characteristics of useful financial information places less emphasis on understandability and instead stresses the following:

- relevance,

- faithful representation.

As far as relevance is concerned, the information received by users will have achieved this quality if it has predictive value, confirmatory value or both of these things. If we are thinking of faithful representation, though, we have in mind information that is complete, neutral and free of errors.

According to the new IFRS approach, the following characteristics are now of secondary importance:

- comparability,

- verifiability,

- timeliness,

- and understandability.

In its references to the "understandability of financial statements", the Conceptual Framework for Financial Reporting emphasises clarity and conciseness in the classification, characterisation and presentation of information. There is no requirement for this information to be understandable to all users, or even to all those with a good general knowledge of business.

According to Hendriksen and Van Breda (Hendriksen \& Van Breda 2002) qualitative characteristics in accounting theory are defined as those that stand the test of time, that are commonly used by entities and are subject to verification. It was assumed that the information must have quality characteristics such as:

- relevance,

- credibility,

- use benefits that outweigh acquisition costs,

- understandability,

- comparability between companies.

| ${ }^{5}$ See, for example, Ball (2006), Williams \& Ravenscroft (2015) and Gebhardt et al. (2014). 
In this reading understandability is tailored to the user. In this way advanced users receive the more sophisticated and comprehensive material they require and users with a lower level of accounting knowledge are presented with material that is more immediately accessible (Hendriksen \& Van Breda 2002).

According to Micherda (Micherda 2014, p. 18), on the other hand: "the quality of information produced in accounting can be interpreted as a set of features which determine the ability to meet the requirements arising from the function accounting performs." In this approach, the following are the most important determinants of information quality:

- Is it feasible?

- Does it have cognitive value?

- Is it operative?

- Is it economical?

According to this classification, intelligibility is associated with cognitive value and depends on the structure of information. A desirable structure is one that meets the needs of management by combining information in sufficient detail and in relevant sections (Micherda \& Świetla 2013, p. 44).

One of the postulates of the theory is the pursuit of ideal financial reporting, which should identify and evaluate all items properly so that the equity's book value reflects a company's value to shareholders, and the balance sheet value reflects the total value of an enterprise for both the shareholders and creditors (Grabiński et al. 2014, p. 204).

In the theory of accountancy the balance sheet, which is that part of a financial statement with the longest history, is still referred to as a "snapshot" of an enterprise that reflects a specific moment in time (Davies \& Boczko 2005; Wędzki 2009, p. 51). At the same time research has confirmed that, despite the fair application of the law, the information contained in financial statements may not provide a true picture of a company's value or its individual assets (Alexander \& Nobes 2007; Mączyńska 2009, Szczesny \& Valentincic 2013, pp. 285-317; Bauer 2014). The figures presented in the balance sheet and in other parts of financial statements should therefore be supplemented with additional information and explanations.

Descriptive information can have a positive influence on the understandability of the information contained in financial statements. Yet producing reliable and relevant descriptive information for financial statements is not easy as it requires the preparation of a clear text that contains all of the relevant data. The effort is worth making, though, as 
this information helps us to obtain a comprehensive picture of a company's financial situation (Krasodomska 2011, p. 103).

\section{The Influence of Legal Regulations on the Understandability of Financial Statements during the Bankruptcy Process}

\subsection{The Information Needs of External Users during Bankruptcy}

According to Hendriksen \& Van Breda (Hendriksen \& Van Breda 2002) one of the key elements of financial reporting is the proper definition of the information's target users.

Some narrow down these target groups to members of the board, while others include all members of the public. Though the Conceptual Framework for Financial Reporting specifies investors, lenders and other creditors as the main users of the information presented in financial statements, it does not exclude the possibility that financial statements may be a source of information for other parties, such as regulators and members of the public.

At different stages of bankruptcy proceedings the following are the target users of information presented in financial statements:

- during the initial phase: all creditors who have filed for bankruptcy,

- in actual proceedings: all creditors,

- throughout the bankruptcy proceedings: debtors and those at court who decide whether or not bankruptcy proceedings can be conducted (temporary supervisors/administrators, court experts, judges ruling on declarations of bankruptcy).

As they are in clear need of credible and reliable information on the financial condition of debtors, judges ruling on declarations of bankruptcy make up a specific group of external users. The questions they consider most often when making a decision are as follows:

- Are the debtor's assets sufficient to cover the costs of bankruptcy proceedings?

- To what extent are the debtor's assets sufficient to repay debts?

- Are the assets of greater value if sold? If so, is it more beneficial to declare bankruptcy and liquidate assets? Is the use value of assets higher and is restructuring a better solution?

The following are the minimum requirements for a financial statement to be useful and understandable to users during bankruptcy proceedings:

- a balance sheet, including information about assets throughout several cycles, 
- an income statement, which gives information about the income and expenses incurred by the company in past cycles,

- additional information, defining accepted valuation principles.

The cash flow statement is a further valuable source of information because it contains data on actual cash flow which, especially where there is a threat of bankruptcy, is more important than the accrual recognition of revenues and expenses.

It is the opinion of Wędzki (Wędzki 2013, p. 452) that: “(...) a financial statement is not the only source of information about the financial condition. The question therefore arises of whether it actually contains useful financial data. Confirmation of the thesis that it does in fact contain such data is the widespread use of financial statements in the prediction of bankruptcy". A financial statement may thus act as a foundation for assessing whether a company can survive once restructuring is complete. It may also provide grounds for evaluating the board in the periods preceding the filing of the bankruptcy petition. If this is to happen, however, access to both complete financial data, and to additional information that enables users to understand the contents of financial statements, is required (Bauer 2009).

\subsection{The Financial Reporting of Companies in the Process of Bankruptcy}

There are two main stages in bankruptcy proceedings:

- declaration proceedings,

- actual proceedings.

Declaration proceedings begin when the debtor or creditor submits the bankruptcy petition and end with the court's decision to declare bankruptcy or dismiss the petition. A petition may be dismissed due to a lack of funds to conduct bankruptcy proceedings, because there are no groups to submit a petition or because the entity's financial state is not sufficiently poor to meet the criteria stipulated by the Bankruptcy Act for starting bankruptcy proceedings ${ }^{6}$. If the court decides to admit the bankruptcy petition, it has to decide whether the bankruptcy will lead to liquidation of assets or to an arrangement. The understandability of the data contained in financial statements is crucial when the decision to declare bankruptcy is under consideration.

${ }^{6}$ According to Article 12 of the Bankruptcy and Reorganisation Act, the court may dismiss a bankruptcy petition if the delay in paying liabilities does not exceed three months and the sum of unexecuted liabilities does not exceed $10 \%$ of total assets. 
A court's decision to declare bankruptcy is made based on information from:

- the bankruptcy petition,

- the reports of the interim court supervisor (if one has been appointed),

- the opinion of the court expert (if one has been appointed).

The bankruptcy act in force until the end of 2015 limited the requirements for financial statements submitted to a court with the petition for bankruptcy to a balance sheet prepared no later than 30 days prior to submitting the petition and - where debtors were applying for an arrangement bankruptcy a cash flow statement for the previous twelve months ${ }^{7}$. Failure to submit the required documents with a petition did not, however, prevent the initiation of bankruptcy proceedings. Debtors could be exempted from the obligation to submit the balance sheet and cash flow statement to the court if they specified credible reasons for not attaching these documents to the petition and had proof of them.

The Bankruptcy Act determines the scope of accounting information included in the documentation accompanying the bankruptcy proceedings.

In summary, representatives of the law in bankruptcy proceedings may require the submission to court of the balance sheet and, in certain cases, the cash flow statement, only insofar as the debtor has no grounds on which to apply for an exemption from this requirement.

As there is no obligation to attach additional information to financial statements, it is open to question whether the contents of the balance sheet in bankruptcy proceedings can be understood by external users who do not have access to supplementary information.

For example, the balance sheet values do not in themselves provide information on what valuation principles have been applied. It must be presumed that debtors applying for bankruptcy leading to the liquidation of the assets of the insolvent debtor make their valuations in accordance with Art. 29 of the Accounting Act $^{8}$ on the assumption that business operations will not continue. That is: "the undertaking's assets are measured at net realisable selling prices no higher than their acquisition prices or manufacturing costs, less any accumulated depreciation or amortisation charges as well as impairment losses recognised so far".

By contrast, debtors applying for arrangement bankruptcy might expect to continue business operations - either in a significantly different area of

\footnotetext{
${ }^{7}$ Article 23 of the Bankruptcy and Reorganisation Act of 28 February 2003.

${ }^{8}$ Accounting Act of 29 September 1994.
} 
business or within the current scope - and therefore make the valuation in accordance with Art. 29 or Art. 28.

The valuation method according to Art. 28 applies to entities whose continued operation is not threatened. In this case, the valuation methods vary for different groups of assets. The implementation of the law does not therefore provide the necessary information on the valuation method used, and nor does it help in understanding the financial data.

The implementation of the provisions of the Bankruptcy Act may also affect the comparability of individual values over time, which is also connected to the understandability of the data included in financial statements. The threat of bankruptcy can cause dynamic changes in the scope of property and financial resources owned. Polish law stipulates the submission of a balance sheet prepared just for one day, not later than 30 days before the petition is submitted. Debtors are therefore not required to submit a balance sheet for another day, such as at the end of the fiscal year, at the same time. This approach restricts the capacity to understand the changes that have taken place over time and that have led to the filing of a bankruptcy petition.

In short, if debtors submit documentation for bankruptcy proceedings drawn up in strict accordance with the requirements of the Bankruptcy Law, they will not be providing information users with data regarding valuation rules, revenue amounts, costs and performance. Furthermore, users will not be in a position to compare quantified values over time. The financial statements accompanying bankruptcy proceedings are not adequate to the task of making a reliable assessment of a debtor's financial situation. Courts must therefore analyse other documents in order to make an evaluation. In this regard, the documents prepared by the interim court supervisor as grounds for the court to rule on declaring bankruptcy are:

- an estimate of debtors' assets (Bauer 2014),

- cost accounting for the bankruptcy proceedings (Bauer 2013).

\section{The Practice of Financial Reporting in Bankruptcy Proceedings in Poland}

\subsection{Sample Selection}

The research focused on the quality of financial statements as a component of databases supporting bankruptcy proceedings, with particular emphasis placed on their understandability. Records from 2011 of 
100 cases of bankruptcy proceedings in which bankruptcy had been declared were examined.

Empirical research was carried out in four of the forty-six district courts conducting insolvency proceedings in Poland. These included courts in:

- Tarnów (3 cases),

- Warsaw (22 cases),

- Katowice (26 cases),

- Kraków (49 cases).

The courts in the study were selected with a specific aim in mind. The court in Tarnów belongs to the group of courts with the smallest number of declared bankruptcies, the courts in Katowice and Kraków have an average number and the Warsaw court, which deals with approximately 150 cases every year, has the largest number of declared bankruptcies in Poland. Though documentation for all of the available bankruptcy proceedings in Tarnow, Katowice and Kraków was obtained, the sample size remained insufficient. The documentation required to complete the sample was therefore obtained from the Warsaw court. The aim was to achieve a sample of 100 cases representative of the structure of the entire population of insolvent companies in Poland.

Double stratified selection of the research sample was applied according to the legal forms of the bankrupt enterprises during the research period. The following legal forms were represented in the sample:

- 70 limited liability companies,

- 13 individuals engaged in economic activities,

- 7 joint-stock companies, 4 registered partnerships,

- 6 other forms of economic activity, such as limited partnerships and cooperatives.

The proportion according to legal forms of the enterprises in the research sample is similar to that of the total insolvencies declared in the 2011 Report (2012).

At the same time, the sample selection was made in accordance with the type of insolvency proceeding. The sample comprises:

- 16 cases of arrangement bankruptcy,

- 84 cases of proceedings leading to the liquidation of the debtor's assets.

The sample size corresponds to 14\% of all insolvency cases in 2011 and is fundamentally representative of the phenomenon in Poland.

The research results presented here are part of a project concerning the limitations on, and potential for, using information from enterprises' accounting documents in bankruptcy proceedings. 


\subsection{Research Results}

Due to the research topic, which is the understandability of the financial statements at the stage of deciding a company's future, the empirical studies documented the bankruptcy process from the date of filing for bankruptcy to the date of declaring it.

Close attention has been paid to the particular elements of the financial statements included in the information database supporting the bankruptcy proceedings.

Table 1. Elements of Financial Statements in Bankruptcy Proceedings Documentation

\begin{tabular}{l|c}
\hline \multicolumn{1}{c|}{ Elements of a financial statement } & $\%$ of cases \\
\hline Balance Sheet, including: & 93 \\
\hline - drawn up on a day not later than 30 days prior to submission of petition & 84 \\
\hline - drawn up at the end of the fiscal year (submitted with petition) & 71 \\
\hline - drawn up on a different day & 35 \\
\hline Statement of Cash Flows, included in: & 11 \\
\hline - case files relating to requests for proceedings leading to an arrangement & 8 \\
\hline - case files relating to requests for liquidation of assets & 3 \\
\hline Introduction to financial statements, including: & 21 \\
\hline - information on the going concern assumption & 17 \\
\hline Profit and Loss Account & 78 \\
\hline Statement of Changes in Equity & 2 \\
\hline
\end{tabular}

Source: author's own study.

The research found that:

- in $93 \%$ of cases, in accordance with the Bankruptcy Act, a balance sheet had been drawn up and submitted not later than 30 days prior to filing a petition. In only one case was a balance sheet not submitted with a debtor's petition. In the remaining cases in which a balance sheet had not been submitted it was because the bankruptcy petition had been filed with the court by a creditor,

- the case in which a court found and challenged a significant difference between assets and liabilities deserves particular attention,

- a cash flow statement was submitted in $11 \%$ of cases, including three cases in which the petitions were filed by debtors intending to initiate asset-liquidation proceedings, 
- most debtors submit more elements of financial statements than required by law. A profit and loss account was included in $78 \%$ of cases, financial statements information was included in $19 \%$ of cases and a statement of changes in equity in $2 \%$ of cases,

- in two cases the introduction to the financial statements did not contain any information on the rules adopted concerning the continuation of business operations,

- special attention is merited by three cases in which debtors filed for asset-liquidation bankruptcy, but in the introduction to the financial statement stated that the application had been drawn up assuming the business would remain a going concern within the same scope of business for the foreseeable future,

- though debtors submitted more elements of financial statements than required by law, comparable value over time was relevant in $24 \%$ of cases. This was observed particularly in cases where a bankruptcy petition was submitted in January and was therefore accompanied by a financial statement, or selected parts of a financial statement, for the fiscal year just ended and for the previous fiscal year. In two cases, debtors who were trying to ensure comparability over time submitted profit and loss accounts for the same period of time (less than a year) for two consecutive years.

In summary, though the Bankruptcy Act greatly minimises the requirements placed on financial statements in bankruptcy proceedings, debtors expand the scope of the accounting documentation about their enterprises that they submit to court.

Additional sections of financial statements had in some cases been added to the court supervisors' interim reports. While court supervisors do not rely on accounting principles when preparing reports required by law, their analyses are more credible for taking these additional sections of financial statements into account.

The current state of affairs should be considered valid from the point of view of implementing the law. The fact that the information database supporting bankruptcy proceedings includes a wider range of accounting documents than required by the Bankruptcy Act is also a positive factor. It is unsatisfactory, however, that the cases in which comparisons are made over time, and in which it is possible to obtain information on the rules adopted to prepare financial statements, depend on the "goodwill" of the parties involved in the bankruptcy proceedings instead of on the law, which should be construed so as to guarantee the delivery of accurate information on the financial situation of debtors. 
Despite debtors' voluntary submission of a larger number of financial statements than required by law, it cannot be stated that the understandability of the content of financial statements is in practice guaranteed.

\section{Conclusion}

The Bankruptcy Act imposes only minimal requirements for the financial statements companies submit to court with a petition for bankruptcy. Users are thus deprived of information from case files, of reliable information on the balance sheet valuation method used to evaluate the debtor's assets, and of information on the costs, results, and revenues generated during the periods preceding the filing of the bankruptcy petition.

The study revealed that, despite the modest legal requirements regarding the financial statements of companies petitioning for a declaration of bankruptcy, most debtors volunteer more elements of financial statements than are required by law. The reason for this may lie in the characteristics of accounting, that is, in the perception that financial statements are a source of reliable information on the assets and financial condition of a company and, as such, may have a profound effect on courts' decisions to declare bankruptcy. The reason companies filing for a declaration of bankruptcy exceed the statutory requirements with regard to sections of financial statements may also be connected with the type of bankruptcy proceedings used. There may be a variety of reasons - other than ethical ones - for attempting to make information about a company's condition credible. Yet the availability of more information about the condition of companies in the form of additional sections in financial statements is to be regarded as positive at the present stage of research.

Though the satisfactory implementation of the Bankruptcy Act's requirements for the submission of financial statements to court, and debtors' attempts to exceed the legal requirements for the information they present, should be emphasised and noted, it must be stated clearly that neither the provisions of the Bankruptcy Act, nor the practice of bankruptcy proceedings in Poland, have brought understandability to the financial statements included in court files for bankruptcy proceedings. Instead, the court must rule in bankruptcy cases by reference to information from other sources.

The law should make provision for the understandability of financial statements in the insolvency process by ensuring that more sections from them, and especially the notes, are made available. Understandability also requires the comparability of data over time, which can be accomplished by 
submitting comparative data for periods preceding the application to the courts. Having said this, the changes which were introduced in 2016 point to further marginalisation of the role of accounting information in liquidation and restructuring proceedings (Bauer 2015).

The present paper represents a preliminary investigation of the potential for introducing the principles of understandability to financial statements in bankruptcy proceedings. It is hoped that future research will extend this perspective 1) by addressing the satisfaction of all of the criteria for the usability of financial statements published by companies in bankruptcy proceedings and 2) by considering a new type of judicial process: restructuring.

\section{Bibliography}

Accounting Act of 29 September 1994 (Journal of Laws 1994, No. 121, item 591, as amended).

Alexander, D. And Nobes, Ch. (2007) Financial Accounting: An International Introduction. Essex: Prentice Hall / Financial Times.

Ball, R. (2006) "International Financial Reporting Standards (IFRS): Pros and Cons for Investors". Accounting and Business Research" 36: 5-27.

Bankruptcy and Reorganisation Act of 28 February 2003 (Journal of Laws 2003, No. 60, item 535, as amended).

Bauer, K. (2009) Zarzadzanie informacjami $w$ procesie upadtościowo-naprawczym przedsiębiorstw [Managing information in the process of enterprise bankruptcy and restructuring]. Kraków: Wydawnictwo Uniwersytetu Jagiellońskiego.

Bauer, K. (2013) "Decyzyjny rachunek kosztów postępowania upadłościowego" [The decisional balance sheet in bankruptcy proceedings]. Prace Naukowe Uniwersytetu Ekonomicznego we Wrocławiu No. 289, pp. 43-52.

Bauer, K. (2014) "Fixed Assets Valuation in the Condition of Bankruptcy Risk: The Role of Estimates". Journal of Modern Accounting and Auditing 10 (6): 652-66.

Bauer, K. (2015) "Kierunki zmian sprawozdawczości finansowej w postępowaniu upadłościowym" [Changes in financial reporting in bankruptcy proceedings]. Prace Naukowe Uniwersytetu Ekonomicznego we Wrocławiu No. 388, pp. 229-37.

Davies, T. and Boczko, T. (2005) Financial Accounting: An Introduction. McGraw-Hill Higher Education.

Gawron, K. (2012) "Użyteczność sprawozdania finansowego na dzień poprzedzający ogłoszenie upadłości przedsiębiorstwa" [The usefulness of financial statements on the day preceding the bankruptcy of an enterprise]. Prace Naukowe Uniwersytetu Ekonomicznego we Wrocławiu No. 251, pp. 170-82.

Gebhardt, G., Mora, A. and Wagenhofer, A. (2014) "Revisiting the Fundamental Concepts of IFRS". Abacus 50 (1): 107-16.

Grabiński, K., Kędzior, M. and Krasodomska, J. (2014) Wspótczesna rachunkowość na rynkach kapitatowych [Modern accounting on capital markets]. Warsaw: Difin. 
Hendriksen, E. S. and Van Breda, M. F. (2002) Teoria rachunkowości [The theory of accounting]. Warsaw: PWN.

IFRS (2014) "International Financial Reporting Standards". London: International Accounting Standards Committee Foundation.

Krasodomska, J. (2011) "Komentarz zarządu w świetle wytycznych Rady Międzynarodowych Standardów Rachunkowości” [Management board reports in light of International Accounting Standards guidelines]. Zeszyty Teoretyczne Rachunkowości 61: 89-106.

Kumor, I. and Strojek-Filus, M. (2011) “Odzwierciedlenie skutków upadłości likwidacyjnej przedsiębiorstwa w sprawozdaniu finansowym" [Reflecting the effects of bankruptcy liquidation in financial statements]. Zeszyty Naukowe Uniwersytetu Szczecińskiego. Finanse. Rynki finansowe. Ubezpieczenia No. 32, pp. 271-81.

Mączyńska, E. (2008) "Wstęp" [Introduction] to E. Mączyńska (ed.) Bankructwa przedsiębiorstw. Wybrane aspekty instytucjonalne [Enterprise bankruptcy. Selected institutional aspects]. Warsaw: Szkoła Główna Handlowa w Warszawie.

Mączyńska, E. (2009) “Zagrożenia w działalności gospodarczej. Dylematy ustrojowo-strategiczne" [Business risk. Systemic and strategic dilemmas] in Meandry upadtości przedsiębiorstw. Klęska czy druga szansa? [The vicissitudes of enterprise bankruptcy. Failure or second chance?]. Warsaw: Oficyna Wydawnicza Szkoły Głównej Handlowej w Warszawie, pp. 31-62.

Micherda, B. (2014) "Jakość informacji finansowych w teorii i regulacjach rachunkowości" [The quality of financial information in theory and in accounting regulations] in B. Micherda (ed.) Teoria rachunkowości a jej wspótczesne regulacje [Accounting theory and its modern regulation]. Warsaw: Difin.

Micherda, B. and Świetla, K. (2013) Wspótczesna rachunkowość. Wybrane problemy metodologiczne [Modern accounting. Selected methodological problems]. Warsaw: Difin.

Report (2012) "Raport Coface nt. upadłości firm w Polsce w 2011 roku” [Coface report on company bankruptcy in Poland in 2011], http://www.coface.pl/CofacePortal/ ShowBinary/BEA\%20Repository/PL/pl_PL/documents/Raport_upadlosci_ caly_2011_COFACE. Accessed: 30 October 2014.

Restructuring Act of 15 May 2015 (Journal of Laws 2015, item 978, as amended).

Smith, D. C. and Strömberg, P. (2004) Maximizing the Value of Distressed Assets: Bankruptcy Law and the Efficient Reorganization of Firms, http://www.sifr.org/PDFs/ smithstromberg\%28wb2005\%29.pdf, pp.1-58.

Szczesny, A. and Valentincic, A. (2013) "Asset Write-offs in Private Firms - The Case of German SMEs". Journal of Business Finance \& Accounting 40 (3 \& 4) (April / May): 285-317.

Walińska, E. and Jędrzejewski, S. (2009) "Bilans w warunkach utraty kontynuacji działalności - zasada ostrożności czy treść ekonomiczna" [The balance-sheet under conditions of loss of business continuity - the precautionary principle or economic substance]. Zeszyty Teoretyczne Rachunkowości 51: 165-76.

Wessels, B., Markell, B. A. and Kilborn, J. J. (2009) International Cooperation in Bankruptcy and Insolvency Matters. A joint research project of the American College of Bankruptcy and the International Insolvency Institute. New York: Oxford University Press. 
Wędzki, D. (2009) Analiza wskaźnikowa sprawozdania finansowego [Ratio analysis of financial statements]. Volume 1: Sprawozdanie finansowe [Financial statements]. Kraków: Wolters Kluwer Polska.

Wędzki, D. (2013) "Użyteczność w teorii sprawozdania finansowego" [Usefulness in the theory of financial statements] in A. Karmańska (ed.) Nauka o rachunkowości na progu gospodarki opartej na wiedzy. Polski sondaż środowiskowy [The science of accounting at the threshold of the knowledge economy. A survey of the Polish environment]. Warsaw: Oficyna Wydawnicza Szkoły Głównej Handlowej w Warszawie, pp. 441-54.

Wędzki, D. (2012) “The Sequence of Cash Flow in Bankruptcy Prediction: Evidence from Poland”. Zeszyty Teoretyczne Rachunkowości 68 (124): 161-79.

Williams, P. F. \& Ravenscroft, S. P. (2015) "Rethinking Decision Usefulness". Contemporary Accounting Research 32(2): 763-788.

\section{Abstract}

\section{Zrozumiałość sprawozdań finansowych w procesie podejmowania decyzji w postępowaniu upadlościowym}

Sprawozdanie finansowe jest jednym ze źródeł informacji o sytuacji finansowej przedsiębiorstwa. O jego wartości informacyjnej świadczy fakt, że jest powszechnie wykorzystywane w predykcji upadłości. W wielu krajach sprawozdanie finansowe lub jego elementy stanowią część bazy informacyjnej procesu upadłościowego. Celem artykułu jest analiza teoretycznych i praktycznych aspektów związanych z wykorzystaniem sprawozdania finansowego jako źródła informacji w procesie upadłościowym na etapie podjęcia decyzji o dalszych losach przedsiębiorstwa dłużnika. Badania aktów prawnych oraz empiryczne przeprowadzono w czterech z 46 sądów prowadzących postępowania upadłościowe w Polsce. W wyniku przeprowadzonych badań stwierdzono, że na obecnym etapie ani regulacje prawne, ani praktyka sądowa nie zapewniają zrozumiałości treści zawartych w sprawozdaniach finansowych w postępowaniach upadłościowych.

Słowa kluczowe: bankructwo, upadłość, zrozumiałość sprawozdań finansowych, jakość sprawozdań finansowych. 